\title{
The dehydration- and ABA-inducible germin-like protein CpGLP1 from Craterostigma plantagineum has SOD activity and may contribute to cell wall integrity during desiccation
}

\author{
Valentino Giarola ${ }^{1,2}\left(\mathbb{D} \cdot\right.$ Peilei Chen ${ }^{1,3} \cdot$ Sarah Jane Dulitz ${ }^{1,4} \cdot$ Maurice König ${ }^{1,5} \cdot$ Stefano Manduzio ${ }^{1,6}$. \\ Dorothea Bartels ${ }^{1}$
}

Received: 21 July 2020 / Accepted: 1 October 2020 / Published online: 12 October 2020

(C) The Author(s) 2020

\begin{abstract}
Main conclusion CpGLP1 belongs to the large group of germin-like proteins and comprises a cell wall-localized protein which has superoxide dismutase activity and may contribute towards ROS metabolism and cell wall folding during desiccation.
\end{abstract}

\begin{abstract}
The plant cell wall is a dynamic matrix and its plasticity is essential for cell growth and processing of environmental signals to cope with stresses. A few so-called resurrection plants like Craterostigma plantagineum survive desiccation by implementing protection mechanisms. In C. plantagineum, the cell wall shrinks and folds upon desiccation to avoid mechanical and oxidative damage which contributes to cell integrity. Despite the high toxic potential, ROS are important molecules for cell wall remodeling processes as they participate in enzymatic reactions and act as signaling molecules. Here we analyzed the $C$. plantagineum germin-like protein 1 (CpGLP1) to understand its contribution to cell wall folding and desiccation tolerance. The analysis of the CpGLP1 sequence showed that this protein does not fit into the current GLP classification and forms a new group within the Linderniaceae. $C p G L P 1$ transcripts accumulate in leaves in response to dehydration and ABA, and mannitol treatments transiently induce $C p G L P 1$ transcript accumulation supporting the participation of CpGLP1 in desiccation-related processes. CpGLP1 protein from cell wall protein extracts followed transcript accumulation and protein preparations from bacteria overexpressing CpGLP1 showed SOD activity. In agreement with cell wall localization, CpGLP1 interacts with pectins which have not been reported for GLP proteins. Our data support a role for CpGLP1 in the ROS metabolism related to the control of cell wall plasticity during desiccation in C. plantagineum.
\end{abstract}

Keywords Cell wall remodeling $\cdot$ Desiccation tolerance $\cdot$ Resurrection plants $\cdot$ ROS

\section{Introduction}

Plants are often subjected to rapid environmental changes during their life cycle. The plant cell wall, a complex matrix of polysaccharides and proteins, provides shape, support,

Communicated by Anastasios Melis.

Electronic supplementary material The online version of this article (https://doi.org/10.1007/s00425-020-03485-0) contains supplementary material, which is available to authorized users.

Valentino Giarola

valentino.giarola@fmach.it

Extended author information available on the last page of the article and protection to cells. Cell walls are not static structures, and they must be flexible to permit cell growth, but they must also form barriers to protect cells from pathogen infections and mechanical damage. Cell wall plasticity is the capacity of the cell wall to dynamically respond to developmental and environmental cues (Chen et al. 2019). The composition of the wall polysaccharide chains, their proportions and their interconnections strongly influence cell wall plasticity. Specific cell wall proteins contribute to the functions of cell walls required in different tissues, developmental stages or environmental interactions. The activation or recruiting of cell wall remodeling systems including cell wall-modifying enzymes and $\mathrm{Ca}^{2+}$ ions permit plants to change the rheological properties of their cell walls. Control of ROS metabolism at the cell wall is essential for remodeling mechanisms as 
ROS such as $\mathrm{H}_{2} \mathrm{O}_{2}$ participates in the enzymatic activity of cell wall-modifying enzymes and may also act as signaling molecule in plant-pathogen interactions at the cell wall (Schmidt et al. 2016).

Resurrection plants are a group of several hundred angiosperm plants which can tolerate desiccation in their vegetative tissues (Gaff and Oliver 2013). In resurrection plants, cell walls extensively shrink and fold upon desiccation, but the integrity and continuity of wall structures are maintained and restored when tissues are re-watered (Farrant 2000; Farrant et al. 2003; Willigen et al. 2003). The capacity to survive extreme folding, i.e., to prevent damage due to mechanical stress generated between the protoplasm and the cell wall, must have been acquired through polysaccharide/ protein cell wall complexes and the induction of cell wall complex formations. Dehydration-induced changes in the cell wall architecture and composition as well as the presence of pectin-associated arabinans have been linked to cell wall plasticity in resurrection species (Moore et al. 2006, 2008; Vicré et al. 1999, 2004). Our understanding of cell wall folding mechanisms in resurrection plants is puzzling as species seem to have evolved species-specific strategies to cope with reversible shrinking and folding. Some species like Myrothamnus flabellifolia rely on high constitutive levels of pectic-arabinans, arabinogalactan-proteins and arabinoxylans, whereas others, such as Craterostigma spp., adjust cell wall plasticity via dehydration-induced biochemical reactions (Jung et al. 2019; Moore et al. 2008, 2013). Among such mechanisms, the reduction of the hemicellulose xyloglucan content and modifications of pectin structures have been described (Jung et al. 2019; Vicré et al. 1999, 2004). Monoclonal antibodies directed against pectin and hemicellulose epitopes demonstrated dehydration-induced changes in rhamnogalacturonan I, rhamnogalacturonan II and hemicelluloses and a reduction of pectin methylesterification (Jung et al. 2019).

$C p C R P 1, C p G R P 1, C p W A K 1$, and pcC13-62 genes encode cell-wall-localized proteins in the resurrection plant C. plantagineum (Chen et al. 2019; Giarola et al. 2015b). The abundance of the proteins is modulated during the dehydration and rehydration cycle and thus these proteins are candidates to participate in cell wall folding mechanisms (Giarola et al. 2015b, 2016, 2018; Jung et al. 2019). A yeast two-hybrid screening identified germin-like proteins among cell wall interacting proteins in C. plantagineum (Dulitz 2016).

Germins and Germin-like proteins (GLPs) belong to the cupin superfamily which includes ubiquitous and biochemically diverse proteins containing a six-stranded beta-barrel structure referred to as cupin domain (Khuri et al. 2001). Plant germins and GLPs are phylogenetically separated from other cupins and there is a correlation between protein conservation and function (Khuri et al. 2001). Some GLPs are bi-functional enzymes with both oxalate oxidase (OXO) and manganese superoxide dismutase (Mn-SOD) activities (Woo et al. 2000), others showed only Mn-SOD activity (Pei et al. 2019). Bifunctional germins are often named "true germins" and cluster together in phylogenetic trees (Carter and Thornburg 1999). GLPs have been described to be circadian or developmentally regulated or expressed upon biotic and abiotic stresses (Davidson et al. 2009; Dunwell et al. 2008). For example, the cell wall-associated Sinapis alba L. GLP is differentially expressed during the day/night cycle (Heintzen et al. 1994) whereas the expression of the pine GLP PcGER1 is linked to embryogenesis (Domon et al. 1995; Neutelings et al. 1998). The Nectarin $I$ gene is almost exclusively expressed in tobacco nectar where it is the most abundant protein (Carter and Thornburg 2000). Germin-like transcripts accumulate upon powdery mildew infections in wheat or fire blight apple infections whereas in barley HvGER4d accumulates exclusively upon Blumeria graminis infection (Bonasera and Beer 2002; Schweizer et al. 1999; Zimmermann et al. 2006). Among abiotic stresses, salt, mechanical wounding, drought, cold, aluminum and high temperatures were shown to induce, inter alia, the accumulation of GLPs (Davidson et al. 2009; Hamel et al. 1998; Hurkman et al. 1991; Jiang et al. 2007; Lu et al. 2010; Vallelian-Bindschedler et al. 1998). Half of the rice germins are induced by either both biotic and abiotic factors or by pathogen infection only (Davidson et al. 2009). Two of them, Os01g72290 and Os03g44880, are induced by drought stress whereas OsGER5 protein is down-regulated upon drought (Davidson et al. 2009; $\mathrm{Ke}$ et al. 2009). Stress-responsive GLPs from different taxa generally cluster together and are predicted to be MnSODs (Carter and Thornburg 2000; Khuri et al. 2001). A possible role of germin-like proteins in dehydration is also supported by the observation that transcripts coding for a germin-like protein similar to the Arabidopsis thaliana germin-like protein GLP5A (P92996) were found to accumulate in dried leaves of the resurrection plant Boea hygrometrica (Wang et al. 2009). GLPs and germins are built on average of 220 amino acids and contain three conserved amino acid motifs often referred to as germin Boxes A, B, and C (Barman and Banerjee 2015; Bernier and Berna 2001). Boxes B and $C$ are separated by a 15- to 26-amino-acid intermotif region and contain three conserved histidine residues and one conserved glutamate (Dunwell et al. 2000; Woo et al. 2000). Ancestral relatives have intermotif regions shorter than modern relatives such as cereal GLPs (Khuri et al. 2001). Two conserved cysteines at the $\mathrm{N}$ terminus form an internal disulphide bridge and delimit a hypervariable amino acid region (Bernier and Berna 2001). Germins form a homohexamer (a trimer of dimers) and the three conserved histidines and a glutamate in the B and C boxes are ligands for a single manganese ion in the active site of each monomer (Requena and Bornemann 1999; Woo et al. 2000). This compact beta-barrel structure permits germins to remain functional in extreme conditions (Thompson 
and Eisenberg 1999). Amino acid ligands of manganese are shared with MnSOD enzymes although the overall protein fold of MnSODs and cupins is different. GLPs are divided into eight GLP subfamilies and two bryophyte subfamilies according to sequence similarity (Barman and Banerjee 2015; Lu et al. 2010; Nakata et al. 2004; Zimmermann et al. 2006). SOD activity has been demonstrated for a limited number of GLP subfamily 1 , subfamily 2 , subfamily $5 / 6$, subfamily 7 and bryophyte subfamily 1 and 2 members (Barman and Banerjee 2015).

OXO GLPs are active at low $\mathrm{pH}$ and are likely to be involved in the detoxification of oxalic acid produced by plant pathogens. The SOD function of GLPs is active at neutral $\mathrm{pH}$ and should protect plants from biotic- and abioticinduced oxidative stress (Dunwell et al. 2000; Khuri et al. 2001). Besides the metal-binding domain, an N-glycosylation and an N-terminal signal peptide for cell wall localization are usually present in GLPs (Bernier and Berna 2001).

The objective of this study was to investigate the $C$. plantagineum CpGLPI gene at the transcript and protein level to provide a clue how GLP1 may contribute to cell wall properties required for desiccation tolerance in $C$. plantagineum. $C p G L P 1$ transcripts accumulate in response to dehydration and are transiently induced upon ABA and mannitol treatments in leaves. The CpGLP1 protein accumulates in protein extracts enriched for cell wall proteins thus supporting an extracellular localization. CpGLP1 weakly interacts with pectins and has SOD activity suggesting that it may be involved in oxidative stress management linked to cell wall protection/remodeling during dehydration.

\section{Materials and methods}

\section{Plant materials and treatments}

C. plantagineum Hochst. plants were grown according to Bartels et al. (1990). Plants were dried and rehydrated in pots for the indicated time. The relative water content (RWC) of dehydrating leaves was determined according to Bernacchia et al. (1996). For osmotic and ABA treatments, fully grown leaves of well-watered plants were detached and incubated for the indicated time in $0.5 \mathrm{M}$ mannitol or $100 \mu \mathrm{M}$ ABA, respectively. Leaves, incubated in water, were used as control. Leaf tissues were ground in liquid nitrogen and stored at $-80{ }^{\circ} \mathrm{C}$ or freeze-dried.

\section{Identification of CpGLP1 homologs and phylogenetic analysis}

Proteins similar to the $C$. plantagineum germin-like protein 1 (CpGLP1; GenBank accession number MT978083) were identified from Lindernia brevidens, Lindernia subracemosa and Oropetium thomaeum transcriptome data (VanBuren et al. 2015, 2018) or GenBank using the CpGLP1 predicted protein sequence as the query. CpGLP1 homologs were aligned with T-Coffee (https://tcoffee.crg.cat/apps/tcoff ee/do:regular) (Notredame et al. 2000) and the sequence alignment was input in MEGA X (Kumar et al. 2018) to reconstruct the evolutionary gene history. The phylogenetic analysis was conducted using the Maximum Likelihood method based on the JTT matrix-based model (Jones et al. 1992). The tree with the highest log likelihood (- 7086.76) is shown in Fig. 1b. The full sequence alignment between Lindernia GLPs and selected similar GLPs from GenBank (Fig. S1) was used to generate alignments of germin Boxes $\mathrm{A}, \mathrm{B}$, and $\mathrm{C}$ which are shown in Fig. 1c. Sequence alignment of CpGLP1 homologs was used to generate sequence logos using WebLogo 3 (https://weblogo.threeplusone.com/) (Fig. 1c). Lindernia GLPs were also aligned to GLPs from different groups to generate a phylogenetic tree as previously described in Barman and Banerjee (2015) (Fig. S2).

\section{Molecular techniques and sequence analysis}

Molecular techniques were performed as described in Sambrook et al. (1989). Sequencing of DNA and primer synthesis were carried out by Eurofins MWG Operon (https://www. eurofinsgenomics.eu). Protein localization was predicted using the online tools SignalP v. 5.0 (https://www.cbs.dtu. dk/services/SignalP/2 (Almagro Armenteros et al. 2019b) and TargetP-2.0 (https://www.cbs.dtu.dk/services/TargetP/ index.php) (Almagro Armenteros et al. 2019a).

\section{Transcript analysis}

Total RNA was extracted according to Valenzuela-Avendaño et al. (2005). Determination of RNA quality and preparation of cDNA were performed as described in Giarola et al. (2015a) with the following modifications. The amount of total RNA used for DNase I treatment was equal to $500 \mathrm{ng}$ and cDNA samples were prepared from $250 \mathrm{ng}$ of DNase I-treated RNA and finally diluted with water to a final volume of $100 \mu \mathrm{l}$. PCRs were performed with $5 \mu \mathrm{l}$ of diluted cDNA samples. The expression level of CpGLP1 in cDNA samples was determined by RT-PCR with CpGLP1_F (5'TAAACAAGGGCGATGCTTTC-3') and CpGLP1_R (5'CAAAGGTGGGCACTAAATGAA-3') primers. Primers specific for the elongation factor $1 \alpha\left(C p E F 1 \alpha ; 5^{\prime}\right.$-AGT CAAGTCCGTCGAAATGC-3' and 5'-CACTTGGCACCC TTCTTAGC-3') were used to monitor technical variations in cDNA samples. PCRs were repeated with different settings to identify the best amplification conditions for each gene. PCR products shown in Fig. 2 were obtained by either 30 (EFI $\alpha$ and CDeT11-24) or 32 (CpGLPI) amplification cycles. 
a

Box A

MAANGKTSSMFFLI ITASLLAMTRTIFAYDPS PIQDICVADLNSTAVRVNGLPCKDPSTVKADDFFFSGM 70 BOX B 1

DKPGNTTNPIKATFSPVNVRQVPGANTLGLTIARLDFAA GGFLPPHFHPRASEFLMVLKGSMEVGMVIPS 140 BOX C

QGYKLLNKTLN KGAFVVPVGLVHYQRNKAAKGRSTVVFAALNSQNPGLTVLANSVFGATPEIDGGLLAE 210

b

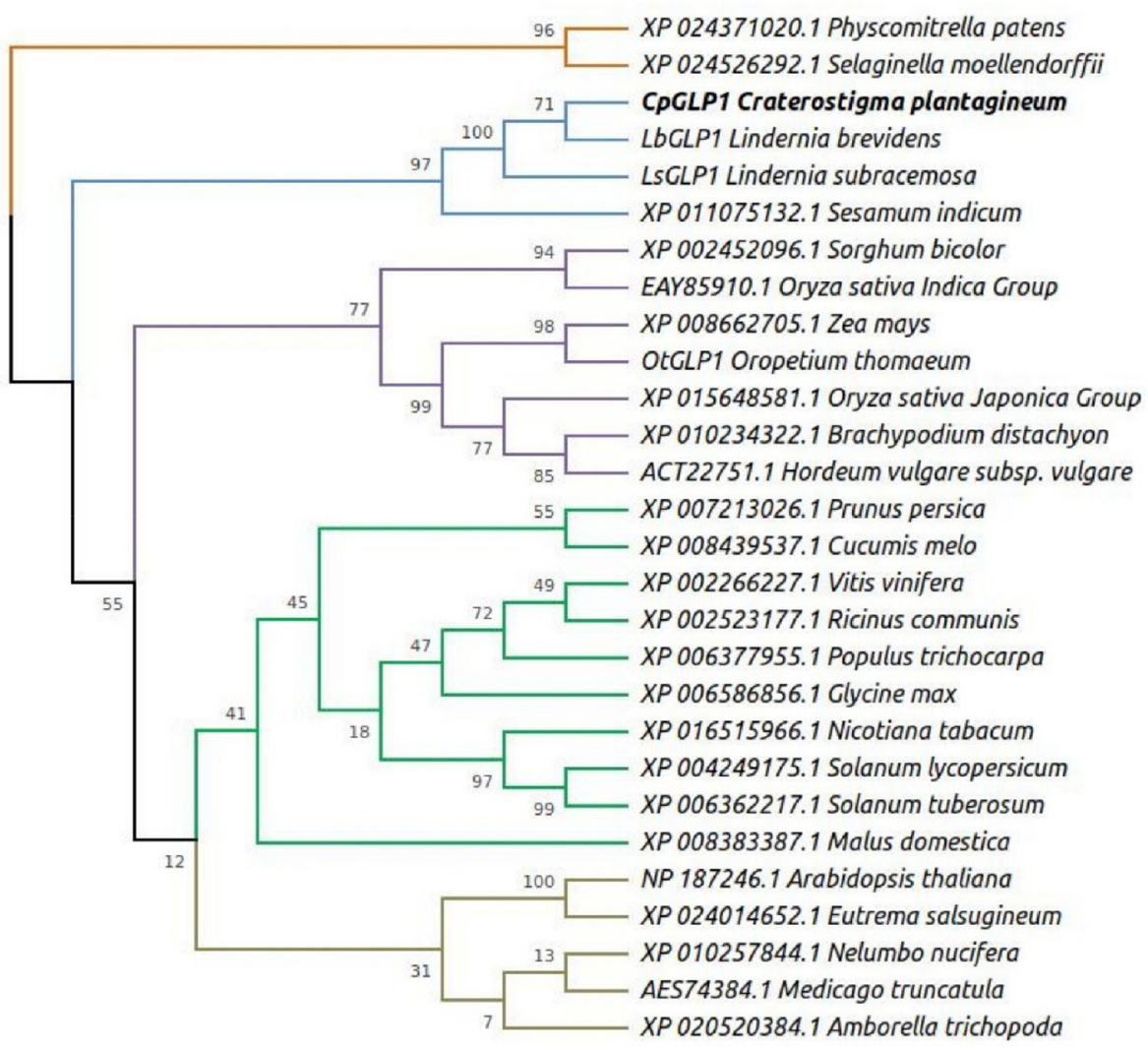

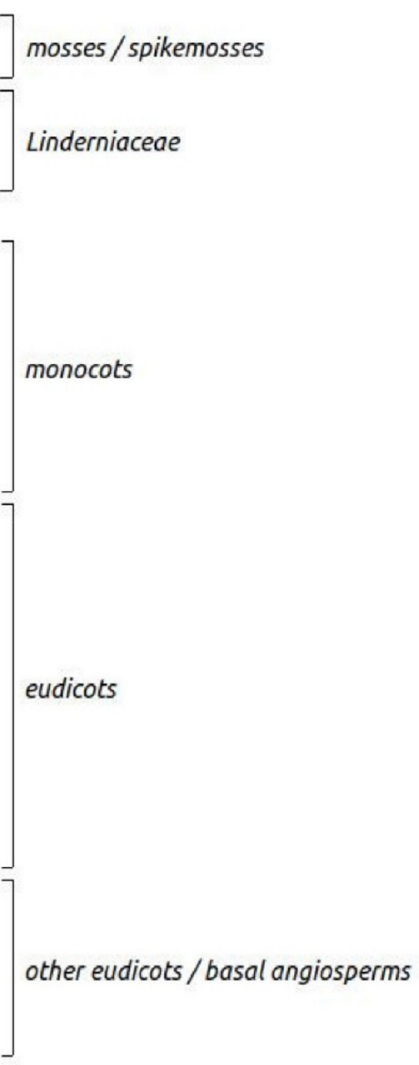

Ath NP 187246.1

Osa EĀ̄ 85910.1

Box A
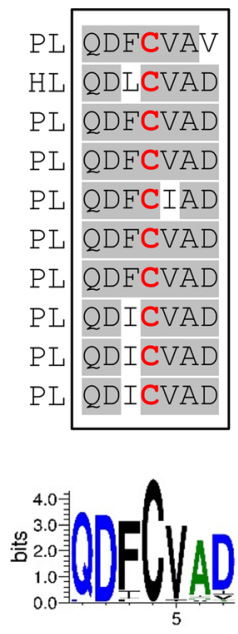

Box C
Box B

GGQNPPHTHPRATEILVVVEG HGLNPPHTHPRATEILTVLEG MGVIPPHTHPRATEILTVLKG LGQNPPHTHPRATEILTVLEG GGINPPHLHPRASEILTVLKG GGQNPPHTHPRATEILTVLEG SGFLPPHTHPRATEIVAVLEG GGFLPPHFHPRASEFLMVLKG GGYLPPHYHPRASEFLMILEG GGYLPPHYHPRASEFLMILEG
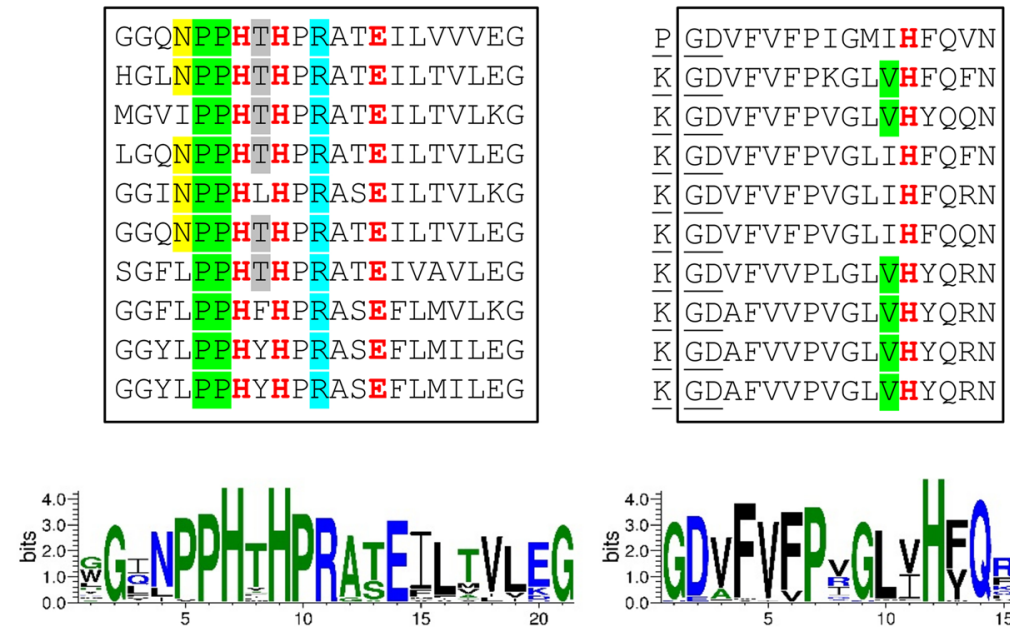

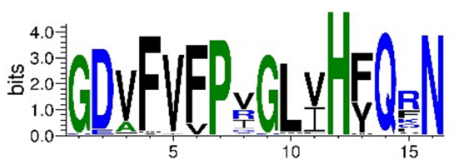


४Fig. 1 Analysis of the Craterostigma plantagineum germin-like protein 1 (CpGLP1) sequence. a CpGLP1 predicted protein sequence. The $C p G L P 1$ sequence was retrieved from our transcriptome databank and cloned to confirm sequence identity. The three sequence motifs which are usually found in germin and germin-like proteins are indicated with rectangular boxes (Boxes A, B, and C) (Barman and Banerjee 2015). The two cysteines that form an internal disulfide bridge are indicated with blue arrows and the four amino acids $(\mathrm{H}$, $\mathrm{H}, \mathrm{E}, \mathrm{H})$ required for the metal ion binding are shown in red. The predicted signal peptide sequence and the KGD motif are underlined with a single and double line, respectively. b Phylogenetic analysis of CpGLP1 homologs inferred using the maximum likelihood method based on the JTT matrix-based model (Jones et al. 1992). The percentage of trees in which the associated taxa clustered together is shown next to the branches. Initial tree(s) for the heuristic search were obtained automatically by applying neighbor-joining and BioNJ algorithms to a matrix of pairwise distances estimated using a JTT model, and then selecting the topology with superior log likelihood value. Evolutionary analyses were conducted in MEGA X (Kumar et al. 2018). c Conservation of amino acid sequence in the three boxes typical of germin and germin-like proteins. Selected CpGLP1 homologs were aligned and the sequences corresponding to Box A, Box $\mathrm{B}$ and Box $\mathrm{C}$ are shown. Amino acids involved in disulfide bonds and metal binding (see a) are indicated in red and amino acids which are conserved in GER 5 and GER 6 classes (Barman and Banerjee 2015) are underlined with colors within the boxes. Sequence logos are shown below sequence boxes to indicate the overall sequence conservation of CpGLP1 homologs. Logos were generated using WebLogo 3 (https://weblogo.threeplusone.com/)

\section{CpGLP1 protein overexpression and production of antiserum}

The protein-coding sequence without most of the predicted signal peptide of CpGLP1 (603 bp, 200 aa) was previously cloned in the yeast two-hybrid vector pAD and was excised from pAD using EcoRI and SalI restriction enzymes. The EcoRI/SalI CpGLP1 fragment (Fig. S4) was subcloned into the expression vector pET28a(+) (Novagen, Darmstadt, Germany) to obtain the N-terminal 6His-tag translational fusion protein CpGLP1His. The correct pET28-CpGLP1His plasmid was confirmed by DNA sequencing and introduced into BL21 (DE3) E. coli cells (Amersham Pharmacia Biotech, Piscataway, NJ, USA) for protein overexpression. BL21 cells carrying the empty pET28 vector were used as a control for expression experiments. E. coli cell cultures carrying the pET28-CpGLP1His and the empty pET28 vector (control) were grown to a density of 0.5 at $\mathrm{OD}_{600}$ and protein overexpression was induced with $1 \mathrm{mM}$ isopropyl-1-thio-bD-galactopyranoside (IPTG) for $5 \mathrm{~h}$ in the dark at $180 \mathrm{rpm}$ and $26^{\circ} \mathrm{C}$. Pellets from 1 and $100 \mathrm{ml}$ bacterial culture were collected by centrifugation and used for SOD activity assays and affinity chromatography, respectively. For affinity chromatography, inclusion bodies were isolated from bacterial pellets (Schmidt et al. 1986) and dissolved in equilibration buffer in $8 \mathrm{M}$ urea/0.1 M sodium phosphate buffer ( $\mathrm{pH}$ 8.0). Resuspended proteins were filtered through a $0.2-\mu \mathrm{m}$ filter (Filtropur S; SARSTEDT, Nümbrecht, Germany) and then purified with the His-Select ${ }^{\circledR}$ Nickel Affinity Gel (SigmaAldrich, Saint Luis, MO, USA) under denaturing conditions following the manufacturer's instructions. CpGLP1His protein was eluted with extraction buffer [0.1 M Hepes ( $\mathrm{pH} 7.9$ ), $6 \mathrm{M}$ urea, $0.5 \mathrm{M}$ imidazole], dialyzed against $6 \mathrm{M}$ urea using a Slide-A-Lyzer ${ }^{\mathrm{TM}} 10 \mathrm{~K}$ Dialysis Cassette (Thermo Fisher Scientific, St Leon-Rot, Germany) and then sent to Seqlab (Sequence Laboratories Göttingen GmbH, Göttingen, DE) to raise a polyclonal antiserum in rabbits. The specificity of the antibody was confirmed using recombinant proteins in protein immunoblots (Fig. S3).

\section{Protein analysis}

Total proteins were extracted from ground leaf material (50-200 mg; according to the leaf RWC) with SDS sample buffer (Laemmli 1970). Cell wall proteins were extracted from $5 \mathrm{~g}$ of ground leaf material according to Printz et al. (2015). The $\mathrm{CaCl}_{2}$, EGTA and $\mathrm{LiCl}$ cell wall extracts were concentrated with Amicon ${ }^{\circledR}$ Ultra $4 \mathrm{ml}$ Centrifugal Filters (Merck KGaA, Darmstadt, Germany), and then precipitated with 4 volumes of cold acetone at $-20^{\circ} \mathrm{C}$. Protein precipitates were dissolved in SDS sample buffer (Laemmli 1970) for protein analysis. For SOD in-gel activity tests, proteins were extracted from bacterial pellets under "semi-native" conditions using a modified SDS sample buffer (without reducing agents) at room temperature (no boiling). Proteins were separated by 10,12 or $15 \%$ (w/v) SDS-poly-acrylamide gel electrophoresis (PAGE) according to Laemmli (1970). SDS gels were either stained with Coomassie blue to monitor equal protein loading or blotted to nitrocellulose membranes for protein immunodetection (Towbin et al. 1979) or used for SOD in-gel activity tests (see below). A 1:5,000 dilution of the polyclonal antiserum was used to detect CpGLP1 protein on nitrocellulose membranes.

\section{Pectin extraction and estimation of protein concentrations}

Pectins were extracted from freeze-dried leaf material (3 mg) with CDTA (1,2-cyclohexanediaminetetraacetic acid) according to Cornuault et al. (2014) with modifications. Briefly, samples were incubated with $1 \mathrm{ml}$ of $50 \mathrm{mM}$ CDTA, $\mathrm{pH} 7.5$, for $1 \mathrm{~h}$ on a shaking platform. Supernatants were collected by centrifugation $(16,000 \mathrm{~g}$ for $15 \mathrm{~min})$ and stored at $-20{ }^{\circ} \mathrm{C}$. The galacturonic acid content of the CDTA fractions was determined according to Verma et al. (2014) and used to check for equal extraction. For that, CDTA fractions $(400 \mu \mathrm{l})$ were mixed with $2.4 \mathrm{ml}$ of $75 \mathrm{mM}$ sodium tetraborate in $\mathrm{H}_{2} \mathrm{SO}_{4}$ and heated in a water bath at $100{ }^{\circ} \mathrm{C}$ for $15 \mathrm{~min}$. Samples were cooled in an ice bath for $10 \mathrm{~min}$ and mixed thoroughly by vortexing with $80 \mu \mathrm{l}$ of m-hydroxydiphenyl solution ( $80 \mu \mathrm{l}$ of $0.5 \% \mathrm{NaOH}$ as blank). 


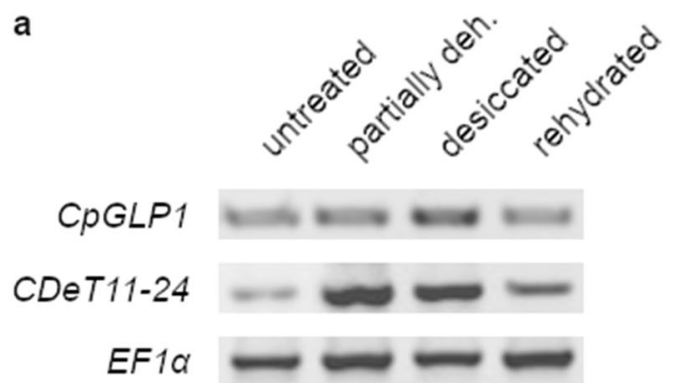

b

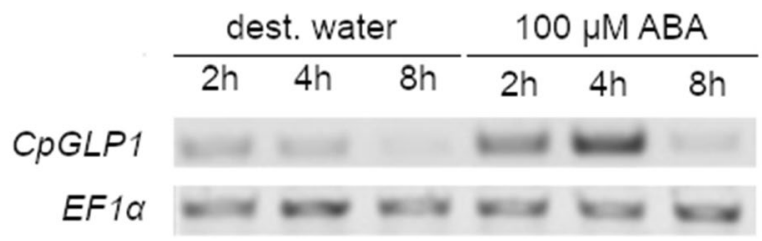

C

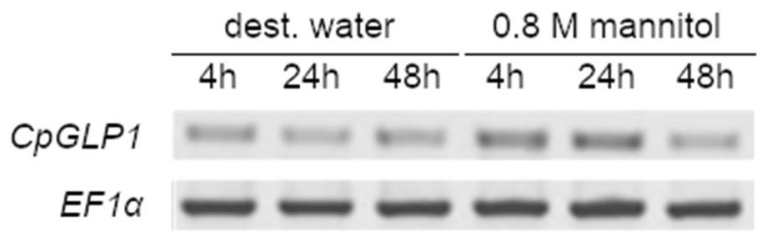

Fig. $2 C p G L P 1$ transcript expression analysis. a Dehydration and rehydration treatments. $C$. plantagineum plants were submitted to a dehydration-rehydration treatment. Samples were taken from untreated (100\% relative water content; RWC), partially dehydrated (50\% RWC), desiccated (2\% RWC) and rehydrated ( $24 \mathrm{~h})$ leaves. b Abscisic acid (ABA) treatment. Fully grown leaves were detached from plants and incubated for $2 \mathrm{~h}, 4 \mathrm{~h}$ and $8 \mathrm{~h}$ in a $100 \mu \mathrm{M}$ ABA solution or in water as control. c Osmotic stress treatment. Fully grown leaves were detached from plants and incubated for $4 \mathrm{~h}, 24 \mathrm{~h}$ and $48 \mathrm{~h}$ in a $0.8 \mathrm{M}$ mannitol solution or in water as control. Expression levels of the elongation factor $1 \alpha(E F 1 \alpha)$ transcript were analyzed in all samples to monitor differences in input cDNA template. Expression of the dehydration-inducible CDeT11-24 transcript was measured as a control for the dehydration rehydration treatment (a). PCR products were obtained by either 30 (EF1 $\alpha$ and CDeT11-24) or 32 (CpGLP1) amplification cycles

Absorbance at $525 \mathrm{~nm}$ was measured with a spectrophotometer after $5 \mathrm{~min}$ incubation at room temperature and the galacturonic acid content was deduced from a standard curve using commercial polygalacturonic acid (Sigma 81325).

\section{ELISA binding assay}

The ELISA binding assay was performed according to Decreux and Messiaen (2005) with modifications. Nunc Maxisorp flat-bottom plate wells (Invitrogen, CA, USA) were coated with commercial pectin from citrus peel
(P9135; Sigma-Aldrich, USA; https://www.sigmaaldri ch.com) or pectin extracted from $C$. plantagineum leaves $\left(250 \mu \mathrm{g} \mathrm{ml}^{-1}, 100 \mu \mathrm{lwell}{ }^{-1}\right)$ at $4{ }^{\circ} \mathrm{C}$ overnight and then wells were incubated with the following solutions for the indicated time: $100 \mu \mathrm{l}$ of $3 \%(\mathrm{w} / \mathrm{v})$ low fat dried milk in wash buffer (20 mM Tris- $\mathrm{HCl}, 150 \mathrm{mM} \mathrm{NaCl}, \mathrm{pH} 8.0$ ) for $2 \mathrm{~h} ; 50 \mu \mathrm{l}$ of purified His-tagged CpGLP1 protein in binding buffer ( $1 \%$ low fat dried milk, $20 \mathrm{mM}$ Tris- $\mathrm{HCl}$, $150 \mathrm{mM} \mathrm{NaCl}, 2 \mathrm{mM} \mathrm{CaCl}_{2}, \mathrm{pH} \mathrm{8.0)}$ for $2 \mathrm{~h}$; wash buffer (four times, briefly); $50 \mu \mathrm{l}$ of anti-His tag antibody $(1: 10,000)$ (Jung et al. 2019) in incubation buffer $(1 \%$ low fat dried milk, $20 \mathrm{mM}$ Tris-HCl, $150 \mathrm{mM} \mathrm{NaCl}, \mathrm{pH}$ 8.0) for $1 \mathrm{~h}$; wash buffer (four times, briefly); $50 \mu \mathrm{l}$ of goat anti-rabbit IgG peroxidase antibody $(1: 10,000)$ (Sigma, A9169) in incubation buffer for $1 \mathrm{~h}$; wash buffer (six times, briefly). The bound recombinant CpGLP1 protein was visualized in the presence of the TMB $\left(3,3^{\prime}, 5,5^{\prime}\right.$-tetramethylbenzidine) substrate (Sigma, T2885). The absorbance was measured at $450 \mathrm{~nm}$ after color development in the dark and the reaction was stopped by adding $50 \mu \mathrm{l}$ of $10 \%(\mathrm{v} / \mathrm{v})$ phosphoric acid.

\section{SOD activity assay}

SOD activity was analyzed in-gel using protein extracts from overexpressing bacteria according to the method described by Beauchamp and Fridovich (1971) and Rucińska et al. (1999).

\section{Sequence data}

$C p G L P 1, L b G L P 1, L s G L P 1$, and $O t G L P 1$ sequences were deposited in the NCBI GenBank database under accession numbers MT978083, MT978084, MT978085, and MT978086, respectively.

\section{Statistical analysis}

Transcript and protein expression analyses, and SOD activity tests were done in triplicate (biological replicates) and one representative picture from these analyses is shown in Figs. 2, 3, and 5, respectively. ELISA binding experiments were repeated trice using three biological replicates (Fig. 4). In ELISA binding experiments, mean and standard error of the mean (SEM) values from three biological and three technical replicates $(n=9)$ were calculated and used to determine statistically significant differences between protein-pectin (+ pectin) and control (- pectin) samples by $t$ tests. Statistical analyses were 


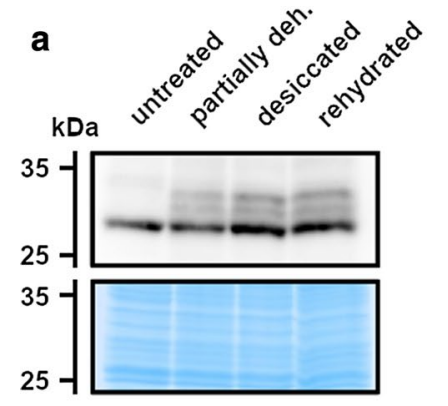

Total proteins

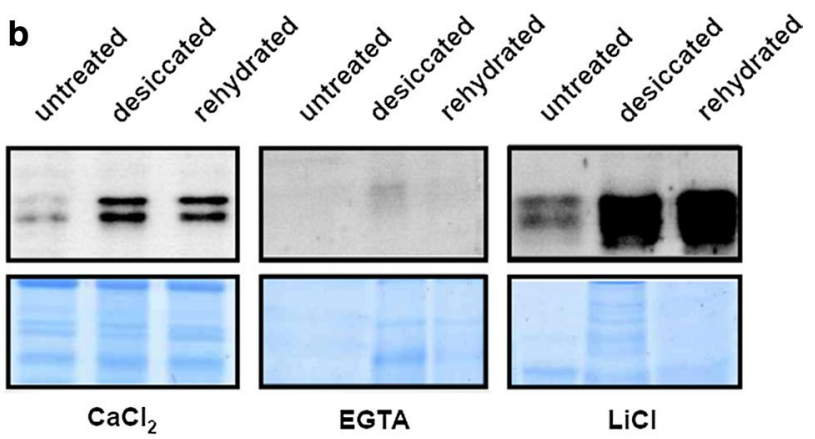

Cell wall proteins
Fig. 3 CpGLP1 protein expression. a Analysis of CpGLP1 protein accumulation was detected in proteins blots using a total proteins and $\mathbf{b}$ cell wall proteins. Total protein samples were prepared from untreated (100\% relative water content; RWC), partially dehydrated (50\% RWC), desiccated ( $2 \%$ RWC) and rehydrated ( $24 \mathrm{~h})$ leaves. Cell wall proteins were prepared from $5 \mathrm{~g}$ using the same untreated, desiccated and rehydrated plant material used for total protein preparations. Briefly, plant material was subjected to sequential washes in

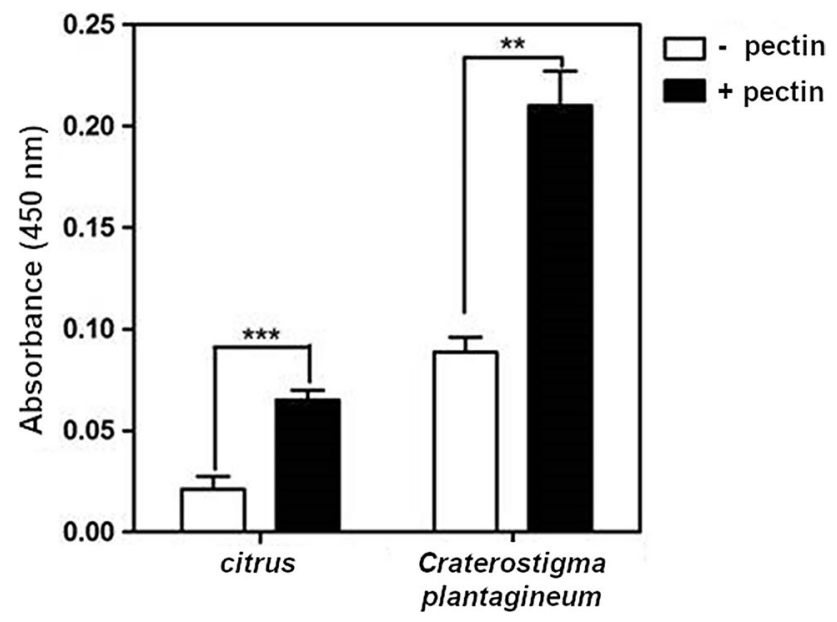

Fig. 4 CpGLP1 protein-pectin interaction assays. ELISA plate wells were coated with solutions supplemented with pectin from citrus peel (P9135; Sigma-Aldrich, Saint Luis, MO, USA) and from C. plantagineum untreated leaves or without pectin. After coating and blocking the wells, wells were incubated with $0.2 \mu \mathrm{g}$ of purified recombinant CpGLP1 protein. The bound CpGLP1 proteins were detected with His-tag antibodies. Mean absorbance values were calculated from three technical and three biological repetitions (mean \pm SEM). Asterisks above bars denote statistically significant differences compared to control (- pectin) samples $(t$-test, $* * P<0.01, * * * P<0.001)$

performed in GraphPad Prism 5.0 (San Diego, CA; https ://www.graphpad.com/). increasing sucrose concentrations, and then cell wall proteins were extracted with $\mathrm{CaCl}_{2}$, EGTA and $\mathrm{LiCl}$ according to Printz et al. (2015). $\mathrm{CaCl}_{2}$, EGTA and $\mathrm{LiCl}$ fractions were concentrated by centrifugation and proteins were precipitated with acetone, resuspended in protein sample buffer and analyzed by $12 \%$ SDS-PAGE. Proteins on SDS gels were transferred to a nitrocellulose membrane for immunodetection or stained with Coomassie blue. Immunoblot analysis was performed with 1:5000 dilutions of the CpGLP1 antiserum

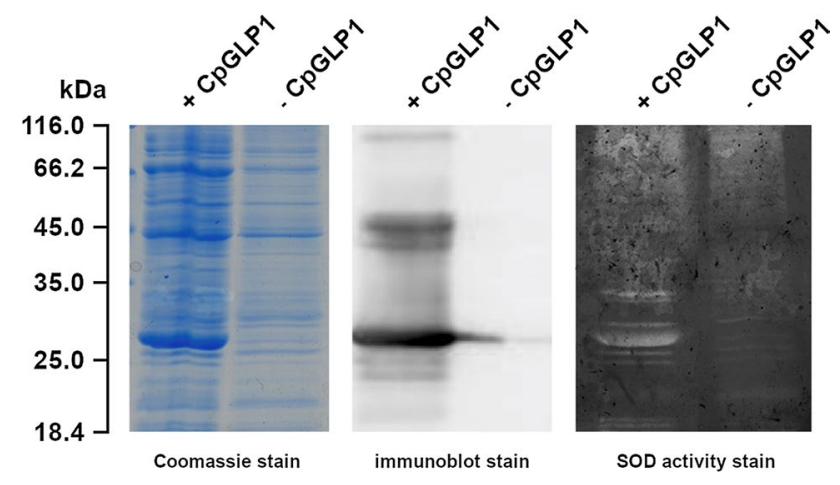

Fig. 5 Analysis of SOD activity. Total proteins were extracted from IPTG-induced BL21 cells harboring the CpGLP1 overexpression vector (+CpGLP1) or the empty vector (- CpGLP1). Protein samples were separated on $12 \%$ SDS gels and gels were either stained with Coomassie blue staining total proteins, or blotted on a nitrocellulose membrane for immunodetection, or used for in-gel SOD enzymatic activity test

\section{Results}

\section{The $C$. plantagineum germin-like protein 1 (CPGLP1) gene}

Screenings for proteins interacting with dehydrationinduced cell wall proteins in $C$. plantagineum identified a germin-like protein (Dulitz 2016). We cloned the fulllength cDNA sequence of the corresponding gene and named it Craterostigma plantagineum germin-like protein 1 (CpGLP1). CpGLP1 encodes a protein of about $21 \mathrm{kDa}$ (without the predicted signal peptide) with an isoelectric 
point of 8.59. The protein sequence of CpGLP1 contains three motifs characteristic for germin and germin-like proteins (Fig. 1a, c). Searches in public databanks identified proteins similar to CpGLP1 in mosses, monocots, and dicots. Putative homologs of $C p G L P l$ were identified in transcriptomic data from Lindernia brevidens and Lindernia subracemosa, two species closely related to $C$. plantagineum but differing in desiccation tolerance (Phillips et al. 2008). The predicted phylogenetic history of CpGLP1 and CpGLP1 homologs is shown in Fig. 1b. The GLP1 homologs clustered according to their phylogenetic subdivision. GLPs from Linderniaceae, i.e., CpGLP1, LbGLP1, and LsGLP1, form a separate cluster from GLPs of other eudicots and mosses, monocots, and basal angiosperms. CpGLP1 and the other Lindernia GLPs could not be assigned to any of the GLP groups which were previously identified (Fig. S2) (Barman and Banerjee 2015). Amino acid sequence conservation within the three typical structural motifs was very high (Boxes A, B, C; Fig. 1c). However, the $\mathrm{N}$ terminus sequence was not conserved (Fig. $\mathrm{S} 1$ ). A KGD motif is found at the $\mathrm{N}$ terminus of the germin Box C in CpGLP1 (Fig. 1). This motif is shared with half of the GLP sequences but not present in germins (Barman and Banerjee 2015).

\section{CpGLP1 is induced by dehydration and ABA}

RT-PCR was used to analyze $C p G L P 1$ transcript levels in untreated $C$. plantagineum plants and plants subjected to dehydration and rehydration. Higher transcript levels were detected in desiccated plants compared to untreated, partially dehydrated, and rehydrated plants suggesting a dehydration-related function for $C p G L P 1$ (Fig. 2a). The hormone ABA is an important mediator of dehydration-induced gene activation, whereas osmotic stress treatments with high concentrations of the sugar mannitol are often able to mimic the induction of dehydration/desiccation-related genes in $C$. plantagineum (van den Dries et al. 2011). Detached C. plantagineum leaves incubated for 2 to $48 \mathrm{~h}$ in $100 \mu \mathrm{M}$ ABA or $0.8 \mathrm{M}$ mannitol showed transient accumulation of $C p G L P 1$ transcripts (Fig. 2b, c). The level of the $C$. plantagineum elongation factor $1 \alpha(E F 1 \alpha)$ transcripts was used as a control for equal amounts of input cDNA in RT-PCR experiments and did not vary among the group of the samples (Fig. 2). The CDeT11-24 transcript (Velasco et al. 1998) was amplified in parallel as control for the dehydration and recovery treatments (Fig. 2a).

\section{CpGLP1 protein accumulates in the cell wall protein fraction of desiccated leaves}

The accumulation of the CpGLP1 protein upon desiccation was analyzed with antiserum raised against the recombinant
CpGLP1 protein. Several proteins of about $28-29 \mathrm{kDa}$ corresponding to the expected size of CpGLP1 were detected by CpGLP1 antiserum in total protein extracts from untreated, partially dehydrated, desiccated, and rehydrated leaf samples. These bands represent CpGLP1 proteins. Figure S3 demonstrates the specificity of the CpGLP1 antiserum, no protein band was detected with pre-immune serum.

Analysis of the protein sequence with localization tools predicted the presence of a signal peptide at the $\mathrm{N}$ terminus suggesting that CpGLP1 is targeted to the apoplast (Fig. 1a). Thus, CpGLP1 protein levels were analyzed in protein fractions enriched for cell wall proteins. Cell wall protein fractions are extracted from cell membranes by sequential extractions with $\mathrm{CaCl}_{2}$, EGTA and $\mathrm{LiCl}$ solutions (Feiz et al. 2006). Protein blot analysis with protein samples precipitated from $\mathrm{CaCl}_{2}$, EGTA and $\mathrm{LiCl}$ extracts are shown in Fig. 3. CpGLP1 proteins are abundant in the $\mathrm{CaCl}_{2}$ and in the $\mathrm{LiCl}$ fractions and accumulate abundantly in the desiccated and rehydrated samples compared to the untreated samples. Control blots with pre-immune serum failed to detect the same protein patterns supporting the specificity of the CpGLP1 antiserum (data not shown).

\section{CpGLP1 protein interacts with pectin}

Because CpGLP1 is localized in the cell wall fraction, it was tested whether CpGLP1 interacts with pectin as a major cell wall component. The interaction of CpGLP1 with pectin was analyzed in ELISA assays using the CpGLP1 recombinant protein and either commercial pectin from citrus or pectin extracted from C. plantagineum leaves (Fig. 4). Absorbance detected from wells coated with citrus or $C$. plantagineum pectin was higher than absorbance detected from wells which were not coated with pectin which shows that CpGLP1 binds to pectin (Fig. 4).

\section{CpGLP1 has SOD activity}

SOD activity has been reported for germin-like proteins (Barman and Banerjee 2015). We investigated whether CpGLP1 also has such an enzymatic activity by in-gel activity assays using protein extracts from bacteria overexpressing the CpGLP1 protein. A band corresponding to the size of the recombinant CpGLP1 protein was strongly visible in-gel assays demonstrating that the CpGLP1 has SOD activity (Fig. 5). No corresponding band was detected in the protein sample from bacteria which did not overexpress the recombinant protein. Other weak bands were stained in both overexpressing and non-overexpressing bacteria which are likely to be bacterial SOD proteins. 


\section{Discussion}

\section{CpGLP1 does not belong to previously described GLP subfamilies}

GLPs are ubiquitous proteins with members in the angiosperms (monocots, dicots), gymnosperms and mosses. GLPs are predicted to be involved in plant development and stress conditions (Barman and Banerjee 2015; Davidson et al. 2009). During screenings for cell wall proteins putatively involved in dehydration-related mechanisms in C. plantagineum, we identify the dehydration-induced GLP gene $C p G L P 1$ which is coding for a protein that contains the typical sequence structures characteristic for most GLPs (Fig. 1a). Clustering of the putative CpGLP1 homologs from different taxonomical clades and groups indicated a clear separation of CpGLP1 from GLPs belonging to other species outside the Linderniaceae family (Fig. 1b) and from GLPs already assigned to existing groups (Fig. S2). The current GLP classification is based on sequence conservation and was introduced following the analysis of GLPs from different species including major cereals (barley, rice, and maize), soybean, Arabidopsis, the moss P. patens (Barman and Banerjee 2015; Davidson et al. 2009; Nakata et al. 2004; Zimmermann et al. 2006). According to this classification, GLPs are divided into nine groups which show specific conserved amino acid residues mostly inside the germin Boxes A, B, and C (Barman and Banerjee 2015). With the exception of $\mathrm{N}$-terminal cysteines and the two histidines and the glutamate residues in Boxes $\mathrm{B}$ and $\mathrm{C}$, the role of amino acid residues which are often conserved in germin boxes is not known and the relationship between these residues and the protein function is missing. Analysis of the CpGLP1 sequence structures correlates to the phylogenetic analysis thus suggesting a separation of CpGLP1 from previously characterized GLPs. Indeed, the CpGLP1 sequence does not contain all the features from one group but rather shares features from different GLP groups. For example, a phenylalanine (F) is mostly found as the third amino acid in Box A of most GLP groups but this residue is not observed in CpGLP1, GER family 5, 6, GER7 subfamily and some bryophyte subfamily members. Proline and leucine (PL) are found before Box A of CpGLP1 and of GLPs from GER family 3, 4, 7, and 8 but not in GLPs from family 5 and 6. At the fourth position in Box B, there is no asparagine $(\mathrm{N})$ in CpGLP1 as observed for all GLP groups except the GER 2 group. Additionally, a threonine (T) residue at position 8 is not found in CpGLP1 and GLPs from GER 1, and some GLPs from the GER 3 and 4 groups and from the bryophyte subfamily 1 and 2 groups (compare Fig. 1c to Fig. 2 from Barman and Banerjee (2015)). Further investigations are required to understand the link between these sequence variations and the function of CpGLP1 from the different groups.

\section{CpGLP1 and desiccation tolerance in $C$. plantagineum}

Several GLP members are stress modulated and were proposed to participate in plant responses to biotic and abiotic stresses (Davidson et al. 2009; Dunwell et al. 2008). CpGLP1 transcripts and proteins accumulate in dehydrating leaves of $C$. plantagineum, thus they could be linked to the ability of this plant to survive desiccation. Two pathways are involved in the activation of dehydration-related genes in plants, i.e., the abscisic acid (ABA)-dependent and the ABA-independent pathways (Todaka et al. 2015). The plant hormone ABA mediates different stress-related and developmental-related processes in plants (Chen et al. 2020). The transcription of dehydration tolerance genes in C. plantagineum can be induced by ABA or mannitol treatments (Bartels et al. 1990; van den Dries et al. 2011). $C p G L P 1$ transcripts transiently accumulate in response to such treatments (Fig. 2b, c) supporting the involvement of dehydration-related signaling pathways in the regulation of CpGLP1 transcription/accumulation. ABA-dependent modulation of GLPs has been observed for other stress-induced GLPs suggesting the importance of this hormone for GLP regulation. For example, the expression of Atriplex lentiformis GLP (AlGLP) is inhibited by ABA treatments (Tabuchi et al. 2003). All peanut GLPs changed their expression levels (were mostly transiently induced) in response to exogenous applications of ABA in seedlings (Wang et al. 2013). In soybean, GLPs from leaves accumulated in response to ABA and PEG (Li et al. 2016). The expression of the rice germin-like protein OsGLP2-1 is increased in response to $\mathrm{ABA}$ and has been shown to be involved in the regulation of seed dormancy (Wang et al. 2020).

\section{CpGLP1 may participate in the ROS metabolism related to cell wall folding}

The regulation of cell wall homeostasis is essential to control cell size and shape during plant development and to protect cell integrity upon stress conditions (Schmidt et al. 2016). Folding of leaves and cell walls is observed in Craterostigma spp. upon desiccation. Available data support the hypothesis that this phenomenon is required to reduce the mechanical and oxidative stress generated by the loss of water and thus protect cellular integrity from lethal damage. (Giarola et al. 2016; Jones and McQueen-Mason 2004; Jung et al. 2019; Vicré et al. 1999, 2004). Cell wall folding is accomplished by a combination of constitutive and inducible mechanisms involving the controlled and coordinated rearrangement of molecular and physical linkage of cell wall structures (Jones 
and McQueen-Mason 2004; Jung et al. 2019; Moore et al. 2008). It has been shown in $C$. plantagineum that these mechanisms may include the specific activation/inactivation of cell wall-modifying enzymes and the accumulation of extracellular $\mathrm{Ca}^{2+}$. Indeed, $C$. plantagineum pectin is de-methylesterified during dehydration and this should, together with calcium accumulation, strengthen the cell wall, or lead to pectin cleavage by polygalacturonases and pectate lyases (Jung et al. 2019). Accumulating evidence suggests that extracellular ROS and ROS metabolism could directly and/or indirectly contribute to modify plant cell wall properties and thus could also participate in shrinking mechanisms in $C$. plantagineum. For example, cell wall peroxidases require hydrogen peroxide as co-substrate to mediate cross-linking of cell wall components but can also produce hydroxyl radicals from hydrogen peroxide which are capable of cleaving cell wall polysaccharides (Burr and Fry 2009; Fry 1998; Lindsay and Fry 2007; Passardi et al. 2004). CpGLP1 has SOD activity (Fig. 5) and accumulates in the cell wall of desiccating leaves (Fig. 3b) and thus could participate in the regulation of the ROS metabolism which controls dehydration-related cell wall remodeling. It has been shown that overexpression of the rice germin-like protein 1 in tobacco led to $\mathrm{H}_{2} \mathrm{O}_{2}$ hyper-accumulation and reinforcement of cell wall components (Banerjee et al. 2010). Thus, CpGLP1 could convert stress-induced hydroxyl radicals to $\mathrm{H}_{2} \mathrm{O}_{2}$ which can then act as signaling molecule or serve as a substrate for, e.g., the peroxidase-mediated cross-linking of cell wall components (Marco and Roubelakis-Angelakis 1996). However, the accumulation of hydroxyl radicals in dehydrating $C$. plantagineum leaves and the identification of dehydration-stress induced or active peroxidases remain to be experimentally demonstrated. Bioinformatic analyses of C. plantagineum dehydrated and rehydrated transcriptomes pointed to an overrepresentation of peroxidase transcripts in rehydrating leaves (Rodriguez et al. 2010).

We showed that CpGLP1 can weakly, but specifically interact with pectins in vitro and that this interaction is much stronger with pectins extracted from C. plantagineum leaves (Fig. 4). Thus, CpGLP1 could possibly interact with specific pectin structures in the cell wall. The interaction with pectin is a novel feature for GLPs and has not been reported for other GLPs so far. CpGLP1 contains a predicted KGD motif. A similar motif, the RGD tripeptide motif is found in animal extracellular adhesion proteins such as fibronectin and vitronectin. The RGD motif of extracellular matrix proteins was shown to function as ligand for integrin receptor proteins (Manjasetty et al. 2005; Ruoslahti 1996). Thus, KGD- and RGD-containing GLPs could interact with other membrane proteins and mediate signal transduction in the extracellular matrix.

A comprehensive study of the apoplastic and membranebound proteins involved in the cell wall ROS metabolism is essential to understand how the extracellular ROS homeostasis is controlled in C. plantagineum and to establish the role of the ROS and the ROS metabolism in the reversible cell wall folding during desiccation and rehydration.

Author contribution statement $\mathrm{VG}$ and $\mathrm{DB}$ conceived and designed the experiments. SJD identified CpGLP1 in yeast libraries and conducted transcript expression experiments. SM prepared antibodies against CpGLP1. PC performed protein expression analysis and protein-pectin interaction experiments. MK did SOD activity tests. VG conducted bioinformatic analysis and wrote the manuscript. DB supervised the work and corrected the manuscript. All authors read and approved the manuscript.

Acknowledgements P. Chen was supported by a scholarship from the Chinese Scholarship Council (CSIC) and S. Manduzio by an ERASMUS fellowship.

Funding Open Access funding enabled and organized by Projekt DEAL.

Open Access This article is licensed under a Creative Commons Attribution 4.0 International License, which permits use, sharing, adaptation, distribution and reproduction in any medium or format, as long as you give appropriate credit to the original author(s) and the source, provide a link to the Creative Commons licence, and indicate if changes were made. The images or other third party material in this article are included in the article's Creative Commons licence, unless indicated otherwise in a credit line to the material. If material is not included in the article's Creative Commons licence and your intended use is not permitted by statutory regulation or exceeds the permitted use, you will need to obtain permission directly from the copyright holder. To view a copy of this licence, visit http://creativecommons.org/licenses/by/4.0/.

\section{References}

Almagro Armenteros JJ, Salvatore M, Emanuelsson O, Winther O, von Heijne G, Elofsson A, Nielsen H (2019a) Detecting sequence signals in targeting peptides using deep learning. Life Sci Alliance 2:e201900429. https://doi.org/10.26508/lsa.201900429

Almagro Armenteros JJ et al (2019b) SignalP 5.0 improves signal peptide predictions using deep neural networks. Nat Biotechnol 37:420-423. https://doi.org/10.1038/s41587-019-0036-z

Banerjee J, Das N, Dey P, Maiti MK (2010) Transgenically expressed rice germin-like protein 1 in tobacco causes hyper-accumulation of $\mathrm{H}_{2} \mathrm{O}_{2}$ and reinforcement of the cell wall components. Biochem Biophys Res Commun 402:637-643. https://doi.org/10.1016/j. bbrc.2010.10.073

Barman AR, Banerjee J (2015) Versatility of germin-like proteins in their sequences, expressions, and functions, vol 15. Springer Verlag, Berlin. https://doi.org/10.1007/s10142-015-0454-z

Bartels D, Schneider K, Terstappen G, Piatkowski D, Salamini F (1990) Molecular cloning of abscisic acid-modulated genes which are induced during desiccation of the resurrection plant Craterostigma plantagineum. Planta 181:27-34. https://doi.org/10.1007/ BF00202321 
Beauchamp C, Fridovich I (1971) Superoxide dismutase: improved assays and an assay applicable to acrylamide gels. Anal Biochem 44:276-287. https://doi.org/10.1016/0003-2697(71)90370-8

Bernacchia G, Salamini F, Bartels D (1996) Molecular characterization of the rehydration process in the resurrection plant Craterostigma plantagineum. Plant Physiol 111:1043-1050. https://doi. org/10.1104/pp.111.4.1043

Bernier F, Berna A (2001) Germins and germin-like proteins: plant doall proteins. But what do they do exactly? Plant Physiol Biochem 39:545-554. https://doi.org/10.1016/s0981-9428(01)01285-2

Bonasera JM, Beer SV (2002) Gene expression in apple in response to inoculation with Erwinia amylovora. International Society for Horticultural Science (ISHS), Leuven, pp 469-475. https://doi. org/10.17660/ActaHortic.2002.590.73

Burr SJ, Fry SC (2009) Feruloylated arabinoxylans are oxidatively cross-linked by extracellular maize peroxidase but not by horseradish peroxidase. Mol Plant 2:883-892. https://doi.org/10.1093/ $\mathrm{mp} / \mathrm{ssp} 044$

Carter C, Thornburg RW (1999) Germin-like proteins: structure, phylogeny, and function. J Plant Biol 42:97-108. https://doi. org/10.1007/BF03031017

Carter C, Thornburg RW (2000) Tobacco nectarin I. Purification and characterization as a germin-like, manganese superoxide dismutase implicated in the defense of floral reproductive tissues. J Biol Chem 275:36726-36733. https://doi.org/10.1074/jbc.M0064 61200

Chen P, Jung NU, Giarola V, Bartels D (2019) The dynamic responses of cell walls in resurrection plants during dehydration and rehydration. Front Plant Sci 10:1698. https://doi.org/10.3389/ fpls.2019.01698

Chen K, Li G-J, Bressan RA, Song C-P, Zhu J-K, Zhao Y (2020) Abscisic acid dynamics, signaling, and functions in plants. $\mathrm{J}$ Integr Plant Biol 62:25-54. https://doi.org/10.1111/jipb.12899

Cornuault V, Manfield IW, Ralet MC, Knox JP (2014) Epitope detection chromatography: a method to dissect the structural heterogeneity and inter-connections of plant cell-wall matrix glycans. Plant J 78:715-722. https://doi.org/10.1111/tpj.12504

Davidson RM, Reeves PA, Manosalva PM, Leach JE (2009) Germins: a diverse protein family important for crop improvement. Plant Sci 177:499-510. https://doi.org/10.1016/j.plantsci.2009.08.012

Decreux A, Messiaen J (2005) Wall-associated kinase WAK1 interacts with cell wall pectins in a calcium-induced conformation. Plant Cell Physiol 46:268-278. https://doi.org/10.1093/pcp/pci026

Domon JM, Dumas B, Laine E, Meyer Y, David A, David H (1995) Three glycosylated polypeptides secreted by several embryogenic cell cultures of pine show highly specific serological affinity to antibodies directed against the wheat germin apoprotein monomer. Plant Physiol 108:141-148. https://doi.org/10.1104/pp.108.1.141

Dulitz S-J (2016) Isolation and characterization of the Craterostigma plantagineum germin-like protein 1 CpGLP1. Master thesis University of Bonn

Dunwell JM, Khuri S, Gane PJ (2000) Microbial relatives of the seed storage proteins of higher plants: conservation of structure and diversification of function during evolution of the cupin superfamily. Microbiol Mol Biol Rev 64:153-179. https://doi.org/10.1128/ mmbr.64.1.153-179.2000

Dunwell JM, Gibbings JG, Mahmood T, Saqlan Naqvi SM (2008) Germin and germin-like proteins: evolution, structure, and function. Crit Rev Plant Sci 27:342-375. https://doi.org/10.1080/07352 680802333938

Farrant JM (2000) A comparison of mechanisms of desiccation tolerance among three angiosperm resurrection plant species. Plant Ecol 151:29-39. https://doi.org/10.1023/A:1026534305831

Farrant JM, Vander Willigen C, Loffell DA, Bartsch S, Whittaker A (2003) An investigation into the role of light during desiccation of three angiosperm resurrection plants. Plant Cell Environ 26:12751286. https://doi.org/10.1046/j.0016-8025.2003.01052.x

Feiz L, Irshad M, Pont-Lezica RF, Canut H, Jamet E (2006) Evaluation of cell wall preparations for proteomics: a new procedure for purifying cell walls from Arabidopsis hypocotyls. Plant Methods 2:10. https://doi.org/10.1186/1746-4811-2-10

Fry SC (1998) Oxidative scission of plant cell wall polysaccharides by ascorbate-induced hydroxyl radicals. Biochem J 332(Pt 2):507515. https://doi.org/10.1042/bj3320507

Gaff DF, Oliver M (2013) The evolution of desiccation tolerance in angiosperm plants: a rare yet common phenomenon. Funct Plant Biol 40:315-328. https://doi.org/10.1071/FP12321

Giarola V, Challabathula D, Bartels D (2015a) Quantification of expression of dehydrin isoforms in the desiccation tolerant plant Craterostigma plantagineum using specifically designed reference genes. Plant Sci 236:103-115. https://doi.org/10.1016/j. plantsci.2015.03.014

Giarola V, Krey S, Frerichs A, Bartels D (2015b) Taxonomically restricted genes of Craterostigma plantagineum are modulated in their expression during dehydration and rehydration. Planta 241:193-208. https://doi.org/10.1007/s00425-014-2175-2

Giarola V, Krey S, von den Driesch B, Bartels D (2016) The Craterostigma plantagineum glycine-rich protein CpGRP1 interacts with a cell wall-associated protein kinase 1 (CpWAK1) and accumulates in leaf cell walls during dehydration. New Phytol 210:535-550. https://doi.org/10.1111/nph.13766

Giarola V, Jung NU, Singh A, Satpathy P, Bartels D (2018) Analysis of pcC13-62 promoters predicts a link between cis-element variations and desiccation tolerance in Linderniaceae. J Exp Bot 69:3773-3784. https://doi.org/10.1093/jxb/ery173

Hamel F, Breton C, Houde M (1998) Isolation and characterization of wheat aluminum-regulated genes: possible involvement of aluminum as a pathogenesis response elicitor. Planta 205:531-538. https://doi.org/10.1007/s004250050352

Heintzen C, Fischer R, Melzer S, Kappeler K, Apel K, Staiger D (1994) Circadian oscillations of a transcript encoding a germin-like protein that is associated with cell walls in young leaves of the longday plant Sinapis alba L. Plant Physiol 106:905-915. https://doi. org/10.1104/pp.106.3.905

Hurkman WJ, Tao HP, Tanaka CK (1991) Germin-like polypeptides increase in barley roots during salt stress. Plant Physiol 97:366374. https://doi.org/10.1104/pp.97.1.366

Jiang Y, Yang B, Harris NS, Deyholos MK (2007) Comparative proteomic analysis of $\mathrm{NaCl}$ stress-responsive proteins in Arabidopsis roots. J Exp Bot 58:3591-3607. https://doi.org/10.1093/jxb/ erm207

Jones L, McQueen-Mason S (2004) A role for expansins in dehydration and rehydration of the resurrection plant Craterostigma plantagineum. FEBS Lett 559:61-65. https://doi.org/10.1016/S0014 -5793(04)00023-7

Jones DT, Taylor WR, Thornton JM (1992) The rapid generation of mutation data matrices from protein sequences. Bioinformatics 8:275-282. https://doi.org/10.1093/bioinformatics/8.3.275

Jung NU, Giarola V, Chen P, Knox JP, Bartels D (2019) Craterostigma plantagineum cell wall composition is remodelled during desiccation and the glycine-rich protein CpGRP1 interacts with pectins through clustered arginines. Plant J 100:661-676. https://doi. org/10.1111/tpj.14479

Ke Y, Han G, He H, Li J (2009) Differential regulation of proteins and phosphoproteins in rice under drought stress. Biochem Biophys Res Commun 379:133-138. https://doi.org/10.1016/j. bbrc.2008.12.067

Khuri S, Bakker FT, Dunwell JM (2001) Phylogeny, function, and evolution of the cupins, a structurally conserved, functionally diverse superfamily of proteins. Mol Biol Evol 18:593-605. https://doi. org/10.1093/oxfordjournals.molbev.a003840 
Kumar S, Stecher G, Li M, Knyaz C, Tamura K (2018) MEGA X: molecular evolutionary genetics analysis across computing platforms. Mol Biol Evol 35:1547-1549. https://doi.org/10.1093/ molbev/msy096

Laemmli UKU (1970) Cleavage of structural proteins during the assembly of the head of bacteriophage T4. Nature 227:680-685. https://doi.org/10.1038/227680a0

Li Y et al (2016) Expression study of soybean germin-like gene family reveals a role of GLP7 gene in various abiotic stress tolerances. Can J Plant Sci 96:296-304. https://doi.org/10.1139/ cjps-2015-0213

Lindsay SE, Fry SC (2007) Control of diferulate formation in dicotyledonous and gramineous cell-suspension cultures. Planta 227:439452. https://doi.org/10.1007/s00425-007-0630-z

Lu M, Han YP, Gao JG, Wang XJ, Li WB (2010) Identification and analysis of the germin-like gene family in soybean. BMC Genomics 11:620. https://doi.org/10.1186/1471-2164-11-620

Manjasetty BA et al (2005) X-ray structure of engineered human aortic preferentially expressed protein-1 (APEG-1). BMC Struct Biol 5:21. https://doi.org/10.1186/1472-6807-5-21

Marco Ad, Roubelakis-Angelakis KA (1996) Hydrogen peroxide plays a bivalent role in the regeneration of protoplasts. J Plant Physiol 149:109-114. https://doi.org/10.1016/S0176-1617(96)80181-7

Moore JP et al (2006) Response of the leaf cell wall to desiccation in the resurrection plant Myrothamnus flabellifolius. Plant Physiol 141:651-662. https://doi.org/10.1104/pp.106.077701

Moore JP, Farrant JM, Driouich A (2008) A role for pectin-associated arabinans in maintaining the flexibility of the plant cell wall during water deficit stress. Plant Signal Behav 3:102-104. https://doi. org/10.4161/psb.3.2.4959

Moore JP, Nguema-Ona EE, Vicré-Gibouin M, Sørensen I, Willats WG, Driouich A, Farrant JM (2013) Arabinose-rich polymers as an evolutionary strategy to plasticize resurrection plant cell walls against desiccation. Planta 237:739-754. https://doi. org/10.1007/s00425-012-1785-9

Nakata M, Watanabe Y, Sakurai Y, Hashimoto Y, Matsuzaki M, Takahashi Y, Satoh T (2004) Germin-like protein gene family of a moss, Physcomitrella patens, phylogenetically falls into two characteristic new clades. Plant Mol Biol 56:381-395. https:// doi.org/10.1007/s11103-004-3475-x

Neutelings G, Domon JM, Membre N, Bernier F, Meyer Y, David A, David H (1998) Characterization of a germin-like protein gene expressed in somatic and zygotic embryos of pine (Pinus caribaea Morelet). Plant Mol Biol 38:1179-1190. https://doi. org/10.1023/a:1006033622928

Notredame C, Higgins DG, Heringa J (2000) T-Coffee: a novel method for fast and accurate multiple sequence alignment. J Mol Biol 302:205-217. https://doi.org/10.1006/jmbi.2000.4042

Passardi F, Penel C, Dunand C (2004) Performing the paradoxical: how plant peroxidases modify the cell wall. Trends Plant Sci 9:534-540. https://doi.org/10.1016/j.tplants.2004.09.002

Pei Y et al (2019) GhABP19, a novel germin-like protein from Gossypium hirsutum, plays an important role in the regulation of resistance to Verticillium and Fusarium wilt pathogens. Front Plant Sci 10:583. https://doi.org/10.3389/fpls.2019.00583

Phillips JR et al (2008) Lindernia brevidens: a novel desiccationtolerant vascular plant, endemic to ancient tropical rainforests. Plant J 54:938-948. https://doi.org/10.1111/j.1365313X.2008.03478.x

Printz B, Dos Santos MR, Wienkoop S, Sergeant K, Lutts S, Hausman JF, Renaut J (2015) An improved protocol to study the plant cell wall proteome. Front Plant Sci 6:237. https://doi. org/10.3389/fpls.2015.00237

Requena L, Bornemann S (1999) Barley (Hordeum vulgare) oxalate oxidase is a manganese-containing enzyme. Biochem $\mathrm{J}$ 343(1):185-190. https://doi.org/10.1042/bj3430185
Rodriguez MC et al (2010) Transcriptomes of the desiccation-tolerant resurrection plant Craterostigma plantagineum. Plant J 63:212-228. https://doi.org/10.1111/j.1365-313X.2010.04243.x

Rucińska R, Waplak S, Gwóźdź EA (1999) Free radical formation and activity of antioxidant enzymes in lupin roots exposed to lead. Plant Physiol Biochem 37:187-194. https://doi. org/10.1016/S0981-9428(99)80033-3

Ruoslahti E (1996) RGD and other recognition sequences for integrins. Annu Rev Cell Dev Biol 12:697-715. https://doi. org/10.1146/annurev.cellbio.12.1.697

Sambrook J, Fritsch EF, Maniatis T (1989) Molecular cloning: a laboratory manual, 2nd edn. Cold Spring Harbor Laboratory Press, New York

Schmidt J, John M, Wieneke U, Krüssmann H-D, Schell J (1986) Expression of the nodulation gene nodA in Rhizobium meliloti and localization of the gene product in the cytosol. Proc Natl Acad Sci USA 83:9581-9585. https://doi.org/10.1073/ pnas.83.24.9581

Schmidt R, Kunkowska AB, Schippers JH (2016) Role of reactive oxygen species during cell expansion in leaves. Plant Physiol 172:2098-2106. https://doi.org/10.1104/pp.16.00426

Schweizer P, Christoffel A, Dudler R (1999) Transient expression of members of the germin-like gene family in epidermal cells of wheat confers disease resistance. Plant J 20:541-552. https ://doi.org/10.1046/j.1365-313X.1999.00624.X

Tabuchi T, Kumon T, Azuma T, Nanmori T, Yasuda T (2003) The expression of a germin-like protein with superoxide dismutase activity in the halophyte Atriplex lentiformis is differentially regulated by wounding and abscisic acid. Physiol Plant 118:523-531. https://doi.org/10.1034/j.1399-3054.2003.00133 $\mathrm{x}$

Thompson MJ, Eisenberg D (1999) Transproteomic evidence of a loop-deletion mechanism for enhancing protein thermostability. J Mol Biol 290:595-604. https://doi.org/10.1006/ jmbi.1999.2889

Todaka D, Shinozaki K, Yamaguchi-Shinozaki K (2015) Recent advances in the dissection of drought-stress regulatory networks and strategies for development of drought-tolerant transgenic rice plants. Front Plant Sci 6:84. https://doi.org/10.3389/ fpls.2015.00084

Towbin H, Staehelin T, Gordon J (1979) Electrophoretic transfer of proteins from polyacrylamide gels to nitrocellulose sheetsprocedure and some applications. Proc Natl Acad Sci USA 76:4350-4354. https://doi.org/10.1073/pnas.76.9.4350

Valenzuela-Avendaño JP, Mota IAE, Uc GL, Perera RS, ValenzuelaSoto EM, Aguilar JJZ (2005) Use of a simple method to isolate intact RNA from partially hydrated Selaginella lepidophylla plants. Plant Mol Biol Rep 23:199-200. https://doi.org/10.1007/ bf02772713

Vallelian-Bindschedler L, Mösinger E, Métraux J-P, Schweizer P (1998) Structure, expression and localization of a germin-like protein in barley (Hordeum vulgare L.) that is insolubilized in stressed leaves. Plant Mol Biol 37:297-308. https://doi. org/10.1023/A:1005982715972

van den Dries N, Facchinelli F, Giarola V, Phillips JR, Bartels D (2011) Comparative analysis of LEA-like 11-24 gene expression and regulation in related plant species within the Linderniaceae that differ in desiccation tolerance. New Phytol 190:75-88. https ://doi.org/10.1111/j.1469-8137.2010.03595.x

VanBuren R et al (2015) Single-molecule sequencing of the desiccation-tolerant grass Oropetium thomaeum. Nature 527:508-511. https://doi.org/10.1038/nature15714

VanBuren R, Man Wai C, Pardo J, Giarola V, Ambrosini S, Song X, Bartels D (2018) Desiccation tolerance evolved through gene duplication and network rewiring in Lindernia. Plant Cell 30:2943-2958. https://doi.org/10.1105/tpc.18.00517 
Velasco R, Salamini F, Bartels D (1998) Gene structure and expression analysis of the drought- and abscisic acid-responsive CDeT11-24 gene family from the resurrection plant Craterostigma plantagineum Hochst. Planta 204:459-471. https:// doi.org/10.1007/s004250050280

Verma C, Singh R, Mishra S (2014) Biochemical characterization of pectin methylesterase from Musa acuminata referring to delayed ripening. IOSR J Pharm Biol Sci 9:42-47. https://doi. org/10.9790/3008-09134247

Vicré M, Sherwin HW, Driouich A, Jaffer MA, Farrant JM (1999) Cell wall characteristics and structure of hydrated and dry leaves of the resurrection plant Craterostigma wilmsii, a microscopical study. J Plant Physiol 155:719-726. https://doi.org/10.1016/ S0176-1617(99)80088-1

Vicré M, Lerouxel O, Farrant J, Lerouge P, Driouich A (2004) Composition and desiccation-induced alterations of the cell wall in the resurrection plant Craterostigma wilmsii. Physiol Plant 120:229-239. https://doi.org/10.1111/j.0031-9317.2004.0234.x

Wang L, Shang H, Liu Y, Zheng M, Wu R, Phillips J, Bartels D, Deng X (2009) A role for a cell wall localized glycine-rich protein in dehydration and rehydration of the resurrection plant Boea hygrometrica. Plant Biol 11(6):837-848. https://doi.org/1 0.1111/j.1438-8677.2008.00187.x

Wang T et al (2013) Characterization of peanut germin-like proteins, AhGLPs in plant development and defense. PLoS ONE 8:e61722. https://doi.org/10.1371/journal.pone.0061722
Wang H, Zhang Y, Xiao N, Zhang G, Wang F, Chen X, Fang R (2020) Rice GERMIN-LIKE PROTEIN 2-1 functions in seed dormancy under the control of abscisic acid and gibberellic acid signaling pathways. Plant Physiol 183:1157-1170. https://doi. org/10.1104/pp.20.00253

Willigen CV, Pammenter NW, Jaffer MA, Mundree SG, Farrant JM (2003) An ultrastructural study using anhydrous fixation of Eragrostis nindensis, a resurrection grass with both desiccationtolerant and -sensitive tissues. Funct Plant Biol 30:281. https:// doi.org/10.1071/fp02221

Woo E-J, Dunwell JM, Goodenough PW, Marvier AC, Pickersgill RW (2000) Germin is a manganese containing homohexamer with oxalate oxidase and superoxide dismutase activities. Nat Struct Biol 7:1036-1040. https://doi.org/10.1038/80954

Zimmermann G, Baumlein H, Mock HP, Himmelbach A, Schweizer $P(2006)$ The multigene family encoding germin-like proteins of barley. Regulation and function in basal host resistance. Plant Physiol 142:181-192. https://doi.org/10.1104/pp.106.083824

Publisher's Note Springer Nature remains neutral with regard to jurisdictional claims in published maps and institutional affiliations.

\title{
Affiliations
}

\author{
Valentino Giarola ${ }^{1,2}$ - Peilei Chen ${ }^{1,3} \cdot$ Sarah Jane Dulitz ${ }^{1,4} \cdot$ Maurice König ${ }^{1,5} \cdot$ Stefano Manduzio ${ }^{1,6} \cdot$ \\ Dorothea Bartels ${ }^{1}$ \\ Peilei Chen \\ chenp1521x@gmail.com \\ Sarah Jane Dulitz \\ Sarah.Dulitz@web.de \\ Maurice König \\ mkoeni22@uni-koeln.de \\ Stefano Manduzio \\ stefano.manduzio.CNU@hotmail.com \\ Dorothea Bartels \\ dbartels@uni-bonn.de \\ 2 Present Address: Department of Genomics and Biology \\ of Fruit Crops, Research and Innovation Centre, Fondazione \\ Edmund Mach, San Michele all'Adige, Italy \\ 3 Present Address: College of Life Sciences, Henan Normal \\ University, Xinxiang 453007, China \\ 4 Present Address: IZMB, University of Bonn, Kirschallee 1, \\ 53115 Bonn, Germany \\ 5 Present Address: Institute of Botany, University of Cologne, \\ Zülpicher Straße 47a, 50674 Cologne, Germany \\ 6 Present Address: Department of Applied Biology, Chonnam \\ National University, Buk-gu, Gwangju, South Korea
}

1 Institute of Molecular Physiology and Biotechnology of Plants (IMBIO), University of Bonn, Kirschallee 1, 53115 Bonn, Germany 